\title{
Szuperszinkron múholdas konstellációk bemutatása és elemzése
}

\section{SZÜKÜLÖ TÉR}

„A világür hatalmas” szoktuk mondani, de a gyakorlati alkalmazások tervezése során egyre inkább rá kell ébrednünk, hogy ez nem igaz. A világür sajnos korlátozott kiterjedésű, és - az alkalmazások szempontjából vizsgálva egyre zsugorodik körülöttünk. Ennek oka egyrészt az égimechanika természeti törvényeiben keresendő, másrészt az emberi tevékenység káros hatásai sajnos már a világürben is érvényesülnek, egyre nehezítve a hasznosítást. Nem véletlen, hogy a NATO Szövetséges Transzformációs Parancsnokság által felkért jövőkutatók is kiemelt fontossággal kezelték az űrt, illetve annak elérhetetlenné tételét: a Visions of Warfare: 2036 című kötet első története evvel a témával foglalkozik.

\section{A KLASSZIKUS MÜHOLDPÁLYÁK ÁTTEKINTÉSE}

A jelenlegi ürrendszerek pályáit a Föld körüli világűrrészben négy nagy pályacsoportba soroljuk:

- a sürű légkör felső határa és a belső Van Allen-öv közötti térrész (hozzávetőlegesen 200-1200 km felszín feletti magasság) az alacsony Föld körüli pálya (Low Earth Orbit, LEO);

- a külső Van Allen-öv legsűrübb része felett, hozzávetőlegesen 20000 km körül található a közepes Föld körüli pálya (Medium Earth Orbit, MEO);

- a Föld tengely körüli forgásával szinkronban történő keringést tesz lehetővé a hozzávetőlegesen 36000 km magasságban lévő geoszinkron pálya (GSO, GEO)

- és a különleges távközlési, távérzékelési, csillagászati alkalmazásokhoz megfelelő erősen nyújtott elliptikus pályák (High Elliptic Orbit, HEO, ezeket gyakran az ott keringő müholdcsaládokról Molnyija és Tundra pályának is nevezik).

Mindegyik pályának megvan a maga specifikus előnye, és hátránya is. A LEO térrész jól alkalmazható távérzékelésre és elegendően nagyszámú összekapcsolt műhold alkalmazásával távközlésre is, de telített üzemelő üreszkö- zökkel és űrszeméttel, amit csak fokozni fog, amikor megvalósulnak az oda tervezett, egyenként ezres-tízezres darabszámú műholdat tartalmazó megakonstellációk. Továbbá, több nemzet is demonstrálta már képességét az itt keringő űreszközök fizikai megsemmisítésére.

A MEO pályákon keringenek a jelenleg üzemelő globális müholdas helymeghatározó rendszerek műholdjai. Ez a pályamagasság jó kompromisszum, mert sokkal kevesebb müholddal lehet a teljes Földet fedő konstellációt építeni, mint a LEO térrészben, a rádiójelek futási ideje azonban (ami kereskedelmi adatátviteli szolgáltatásoknál lenne fontos, bár ilyen szolgáltatást MEO pályáról nem üzemeltetnek) alacsonyabb, mint a GEO pályájú mủholdak esetében. Ugyanakkor - bár a műholdakat a sugárzási öv legsűrủbb magja felett helyezték el -, még mindig igen erős a rájuk áramló részecskesugárzás.

A GSO térrészben, amennyiben 0 fok inklinációjú (pályaelhajlású) körpályára állítjuk az üreszközt, az teljesen szinkronban mozog a földfelszínnel, vagyis a relatív rálátási szög állandó (meghatározott tűréshatárokon belül). Ez a geostacionárius pálya kereskedelmi célokra igen jól hasznosítható, mert a földi állomások antennáinak nem kell követniük a müholdat (nincs relatív elmozdulás), így az állomások könnyen telepíthetők és működtetésük nem túl költséges. Emiatt a GSO térrészben üzemelnek a műsorszóró műholdak, valamint a legtöbb üzleti célú távközlési műhold is. Nullától eltérő pályahajlásszög esetén a műhold az Egyenlítő egy pontja felett egy analemmán oszcillál észak-déli irányban, vagyis szükségessé válik a követése. Bizonyos alkalmazások esetén ez nem hátrány. Abban az esetben ugyanis, amikor az állomást hordozó platform saját mozgása miatt egyébként is szükséges a követés (mozgó járművekre telepített állomások), nem okoz problémát az ehhez képest aránylag kicsi múhold-elmozdulás követése is. A másik tipikus alkalmazás a nagy kapacitású trönkkapcsolatok átvitele, ami igen nagy átmérőjű parabolaantennákat tartalmazó állomásokon keresztül történik. Ezek az állomások még a névlegesen nulla inklinációjú (de a gyakorlatban természetesen egy igen szűk térrészben ugyan, de mégis elmozduló) műholdakat is aktívan köve-
ÖSSZEFOGLALÁS: A geostacionárius pálya jelenleg a müholdas távközlési rendszerekben legelterjedtebben alkalmazott müholdpálya. Ennek elsősorban műszaki okai vannak. Ezt a pályát azonban sok technikai és jogi kihívás fenyegeti. Erre a múltban több példát láttunk, és a jövőben a helyzet várhatóan romlik. Fel kell tehát készülni más pályatartományok alkalmazására. Ez a tanulmány megoldási lehetőségként a geoszinkron pályamagasság feletti, úgynevezett szuperszinkron pályatartomány alkalmazását mutatja be. A tanulmány az Új Nemzeti Kiválóság Program támogatásával készült.
ABSTRACT: The geostationary orbit is the most commonly used orbit in satellite communications systems nowadays. The main reasons behind this are technical. This orbit, however, faces many technological and legal challenges. We have seen examples of this before, and the situation is bound to worsen in the future. We therefore need to start to prepare to utilize other orbits. This article presents a solution by introducing the supersynchronous orbital range and the possible utilization of that. This article was written with the support of the ÚNKP New National Excellence Program.

KEY WORDS: John Draim, supersynchronous satellite, SaVi 
tik, tehát szintén alkalmasak a nagyobb mértékű követő mozgás megvalósítására.

A GEO, GSO pályáknak azonban számos hátrányuk is van - amelyeket korábban felülírt az egyszerű földi állomásokból származó előny -, de napjainkra egyre inkább zavart jeleznek. A kereskedelmi adatátviteli szolgáltatásokban hátrányként jelentkezik a nagy jelfutási idő, amihez a földi hálózatokra tervezett forgalomirányító protokollok ugyan tudnak alkalmazkodni, de sok alkalmazásnál maga a futási idő ténye problémás (például az automatizált tőzsdei kereskedelmi rendszerekben). Ennél sokkal komolyabb, rendkívül jelentős probléma a térrész fizikai telítődése, amit a felhagyott (végleg kikapcsolt, működésképtelen) müholdak még tovább fokoznak. Ezen a magasságon már nem számíthatunk a légkör fékező hatása miatt bekövetkező pályadegradációra - ami ide kerül, az évezredekig itt is marad. A kozmikus sugárzás és a mikrometeorok okozta erózió hatására a felhagyott múholdak szétesnek, a keletkező törmelék pedig tovább fokozza az ütközésveszélyt. A Föld gravitációs inhomogenitása hatására a törmelék kelet-nyugati irányban vándorol, a Hold és a Nap tömegvonzásának együttes hatása (luniszoláris attrakció) pedig észak-déli irányba téríti ki - ezek együttes hatása miatt bízvást számíthatunk arra, hogy aktív emberi beavatkozás hiányában néhány évtizeden belül a GEO térrész az érdemi hasznosításra alkalmatlanná válik. Számos kutató és vállalkozó dolgozik jelenleg is azon, hogy ezt az aktív beavatkozást lehetővé tegye, ezek lehetnének az "on-orbit servicing” (pályán történő kiszolgálás) és „active debris removal” (aktív törmelék-eltávolítás) megoldások. Jogos azonban élnünk a gyanúval és aggodalommal, hogy ezek a rendszerek, amelyek jellegükből adódóan alkalmasak arra, hogy üreszközöket azok együttműködése nélkül elfogjanak és pályájukat befolyásolják, akár (szándékosan, gondatlanságból, tévedésből vagy rosszindulatú befolyásolás hatására) ártó céllal is működhetnek.

A GEO térrésszel kapcsolatban még egy problémát kell megvizsgálni, és ez az igénybevétel jogi szabályozása. A vonatkozó nemzetközi jogforrások (nemzetközi egyezmények) alapján a világűr „az emberiség közös öröksége”, ami mindenki számára hasznosítható, aki képes azt megtenni. A GEO térrész kiemelten fontos gazdasági hasznossága miatt különleges szabályozást igényel, az üreszközök elhelyezését és működését a Nemzetközi Távközlési Egyesület felügyeli. A nemzetközi jog alapvető jellegzetessége azonban, hogy nem kikényszeríthető, hiszen nincs univerzális világbíróság és nincsenek világbírósági végrehajtók sem. De ha lennének is, jelenleg nincs technikai megoldás arra, ha egy üreszköz-üzemeltető nem a neki meghatározott pozícióban, nem a neki meghatározott rádiófrekvenciákon tevékenykedik, akkor kényszer alkalmazásával ezt a zavarást be lehessen szüntetni. Ezzel egyidejüleg azonban már láttunk (akkor sikertelen) példát arra, és nem zárható ki, hogy a jövőben újra felbukkan a GEO térrész nemzeti kisajátításának igénye. A bogotai nyilatkozatban a nyolc egyenlítői ország (Ecuador, Indonézia, Kenya, Kolumbia, Kongó, Uganda, Zaire, valamint Brazília) kifejezte a szándékát annak érdekében, hogy a GEO-pályát nemzeti szuverén területként kezelje, és nemzeti jogában szabályozza annak hasznosítását. Az egyébként logikus, az égi mechanika természeti törvényszerűségeiből levezetett érvelésük akkor elbukott, de mégis azt kell látnunk, hogy a szabályozási környezet szempontjából a GEO térrész különleges a világürben.

Végezetül, a HEO pályák a nevükben hordozzák előnyeiket és hátrányaikat is. Kis számú mủholddal biztosítható a sarkvidéki területek lefedése, a geostacionárius műholdak- hoz alkalmazottnál valamelyest bonyolultabb, a döntött pályasíkú geoszinkron rendszerekben működő űreszközököz hasonló antennákkal, ez napjainkban egyre nagyobb jelentőséggel bír. Azonban amiatt, mert a pálya földközelpontja a LEO térrészben, a földtávolpont pedig a MEO térrészben vagy akár a szinkronpálya magasságában van, a műhold újra és újra áthalad a sugárzási öveken, ami jelentősen megdrágítja a kivitelezését és még így is csak korlátozott élettartammal számolhatunk a besugárzási károsodások miatt.

Ezek a hátrányok, kihívások természetesen ismertek az üripari szakemberek előtt, azonban a gyakorlatban az űrrendszereket azok teljes ipari-gazdasági üzemkörnyezetükben kell vizsgálni. Az űripar jelenlegi válasza a LEO megakonstellációk népszerűsítése, ami a kereskedelmi szolgáltatások követelményeire megfelelő választ ad - amenynyiben nem kezdődik meg a Donald J. Kessler által már több mint 40 éve megjósolt ütközéskaszkád. Figyelembe véve a megakonstellációkba tervezett műholdak magas számát - ami sokszorosan meghalad minden korábbi tervet és modellt - a Kessler-szindróma beindulásának valószínűsége igen magas.

A védelmi célú távközlési, és bizonyos távérzékelési rendszerekben másféle optimalizációs lehetőségekkel számolhatunk. Ezek alapján éppen a jelenleg alkalmazott pályáknál magasabban fekvő pályákat érdemes megvizsgálni. Ezek a szinkronpályánál is magasabban helyezkednek el a Föld körül, nevük ezért szuperszinkron pálya.

\section{A SZUPERSZINKRON MÜHOLDPÁLYÁK BEMUTATÁSA}

A szuperszinkron pályán az űreszköz keringési ideje egy földi napnál hosszabb, így ezeknek a műholdaknak is van relatív elmozdulásuk a földfelszínhez képest, vagyis követést igényelnek. Kiindulási alapunk, hogy a korszerű műveletvezetési rendszerek vezetési pontjai legtöbbször valamilyen jármüplatformon helyezkednek el, így a követés a jármü saját mozgása miatt eredendően szükségszerű. A követést végrehajtó nyalábeltérítési megoldás (akár elektromechanikus, illetve tisztán elektronikus) tehát létezik, csak a vezérlését kell úgy módosítani, hogy a saját mozgás kompenzációja (ami elektronikus iránytű, dőlésszögmérő, gyorsulásmérő szenzorok alapján valósul meg) és a múhold (égimechanikai paraméterek alapján számított) relatív elmozdulásának kompenzációja összegzésre kerüljön.

A nagy (és változó) állomás-műhold távolság rádiótechnikai szempontból komoly kihívást jelent. A szabadtéri rádiócsatorna veszteségei még a legkisebb távolság esetén is meghaladják a geoszinkron pályán tapasztalható értéket, a műhold legtávolabbi helyzetében a csillapítás jelentősen magasabb annál. Ezt a veszteséget a link budget tervezésekor kompenzálni kell, számos eszköz áll a rádiós tervező rendelkezésére ehhez.

Fontos megjegyezni, hogy ezeket a rendszereket jelen tanulmány nem az általános üzleti célú távközlési szolgáltatások nyújtásához, hanem specializált célrendszerekben való alkalmazásra javasolja. (Ez a megoldás összefügg más nehézségek kikszöbölésével.) Eleve olyan adatátviteli protokollokat szükséges tervezni, amelyekben az átvinni kívánt információt reprezentáló bitek és a ténylegesen a rádiócsatornába bemodulált bitek aránya a legmagasabb, vagyis a vezérlő, forgalomirányító többletforgalom minimális. Ez az optimalizáció biztosítja a kisugárzott energia hatékony felhasználását. Tovább segít az információátadásban, ha a forgalmat generáló rendszereket úgy alakítjuk ki, hogy csak a ténylegesen szükséges adatok kerüljenek átvitelre. 
A nagy távolság, ami a csillapítás oldaláról tekintve hátrány, előnnyé változik a mühold fedélzetén lévő antenna nyílásszöge, ezáltal nyeresége szempontjából. Nagyobb távolságból a Föld kisebb szög alatt látszik, vagyis az antenna nyílásszöge kisebb, nyeresége ezzel nagyobb lehet. A később bemutatandó elliptikus pályák miatt a távolság változik, amit aktív adaptív antennával kompenzálhatunk a nyílásszöget mindig a távolsághoz szükséges igazítani.

További nehézség a nagy távolságból eredő, a szinkronpályánál tapasztaltat meghaladó mértékű futási idő. Itt a kidolgozott kommunikációs protokollkészlet a megoldás. Mivel egy specializált célrendszerről, nem pedig kereskedelmi tömegtermékről van szó, megnyílik a lehetőség a teljesen új, optimalizált kialakításra. Az elliptikus pálya miatt ebben az esetben is számolni kell a változó távolság okozta változó futási idővel.

A fenti testreszabások összességében nagy árat jelentenek, azonban vegyük figyelembe, hogy egy teljesen új rendszerről beszélünk, amelyet eleve azért tervezünk, mert a meglévők hosszú időtávú igénybevétele egyre inkább kétségessé válik. A szuperszinkron pálya azonban egy teljesen új térrész az űrben, egy még meghódítatlan terület, és emellett további előnyökkel is rendelkezik.

A később bemutatásra kerülő konstellációkból látni fogjuk, a szuperszinkron pályáról a MEO-hoz képest kisebb számú üreszközzel biztosíthatjuk akár a teljes körű globális szolgáltatásokat, akár csak az északi félteke (ugyanígy a déli, de annak társadalmi-gazdasági értéke kisebb) folyamatos lefedését. Ebbe a körbe a sarkvidéki területek is beletartoznak, amelyeket a geostacionárius müholdak nem látnak be, míg a Molnyija vagy Tundra pályákon keringő müholdak - amelyeket a sarkvidéki fedésre optimalizáltak -, az alacsonyabb földrajzi szélességeken nem biztosítanak megfelelő szolgáltatást. A műholdak között közvetlen kapcsolatok is létesíthetők.

A világür ezen részén a természetes eredetű veszélyforrások (a sugárzás és a mikrometeorok) előfordulása hasonló a GEO térrészhez, az ott szerzett tapasztalatok felhasználhatók az űreszközök tervezésekor. Ez a tér azonban az emberi eredetű szennyezéstől mentes. Nincs ürszemét, és a műholdak relatív elmozdulása csökkenti a rádiófrekvenciás zavarok valószínűségét.

A nagyobb pályamagasság maga után vonja a pályára állítás nagyobb energiaigényét. Azonban a ténylegesen szükséges többlet energia biztosítható. A https://horvath. space/delta-v-calculation/ oldalon bemutatok egy példaszámítást, amely alapján látható, hogy pusztán a megfelelő pályamagasság eléréséhez szükséges energia mindössze 11\%-kal haladja meg a geoszinkron pályamagasság eléréséhez szükséges energiát. A pontos pályára állítási röppálya, és annak energiaigény-megtervezése számos változótól függ (pl. az indítási helyszínről elérhető pályahajlásszögek és a célpálya hajlásszögének viszonya), azonban ugyanez igaz a geoszinkron pályákra is. Az objektíven és egyszerüen összehasonlítható energiaigény a magasság eléréséhez kapcsolódik, ezért választottam ezt a vizsgálat tárgyául.

\section{DRAIMTÓL SZÁRMAZTATOTT ELLIPTIKUS MÜHOLDKONSTELLÁCIÓK}

A nem geostacionárius, folyamatos globális vagy félgömbös lefedést biztosító műholdkonstellációk terén John $\mathrm{E}$. Draim maradandót alkotott. Számos szabadalma közül kiemelkedik kettő, amelyek alapját képezték a jelen tanulmányban bemutatott rendszereknek. Draim munkássága azért tekinthető különlegesnek, mert a korában általánosan elfogadott (és ma is elsődlegesen alkalmazott) körpályák helyett ellipszispályák alkalmazásával tervezett. Kepler második törvénye értelmében az ellipszispályán mozgó műhold keringési sebessége változik, így elérhető, hogy a műhold huzamosabb ideig azon égrészen tartózkodjon, ahonnan hasznos szolgáltatást tud nyújtani, és gyorsan haladjon pályájának azon szakaszán, ahonnan nem hasznosítható jól.

Az első megvizsgált munka az 1989-ben, U.S.Patent 4,809,935 számon szabadalmaztatott Satellites contiuous coverage constellations - a müholdak folyamatos lefedettségi konstellációi, amely 3 vagy 4 műhold alkalmazásával biztosítja a déli vagy az északi félteke ( 3 műholddal), vagy a teljes földfelszín (4 műholddal) való fedését. Hátránya a bemutatott konstellációknak (ez Draim más konstrukcióira is igaz), hogy a „teljes fedés” csak akkor igaz, ha a Föld felszínét közel simának tekintjük. A szabadalomban leírt 3 műholdas, északi féltekét fedő konstellációt modellezve láthatjuk, hogy 2,4 foknál magasabban a horizont fölé emelkedő akadályok már kiesést okoznak a lefedésben. Így hát, miközben Draim tényszerűen valós információt állított, és az általa tervezett rendszer elméletileg képes mindössze három műholddal biztosítani az északi félteke (vagy megfelelően paraméterezve a déli félteke) lefedését, gyakorlati alkalmazhatósága kérdéses. (1. táblázat)

A bemutatott konstelláció lényege, hogy a 3 mühold gyakorlatilag 3 azonos jellemzőjű pályán mozog, de egyrészt a pályasíkok egymáshoz képest a teljes kör egyharmadával, vagyis $120^{\circ}$-kal el vannak forgatva, másrészt a műholdak keringési fázisa is időben elforgatott a teljes keringési idő egyharmadával. (Ezt a megoldást Draim a szabadalmi leírásban a közép-anomáliával jellemezte, amit szintén $120^{\circ}$-onként léptet.) Megtartva ezt az elvet, de 3 helyett 4 pályasíkot alkalmazva elérhetjük, hogy az egyes mủholdak önálló lefedettségi területei között nagyobb legyen az átfedés, vagyis a terepakadályok hatása csökkenthető. Ilyen konstelláció dinamikus szimulációja látható a https://horvath.space/draim-hemispheric/ weboldalon.

Az egyes lefedettségi területdarabok közötti átfedés növelése azért hasznos, mert ezáltal gyakrabban előfordul, hogy egynél több műhold található a (terepakadályok nélkül vizsgált) horizont felett. A földi állomásnak müholdat kell váltania a követő antennarendszere segítségével akkor, ha az éppen használt mủhold lenyugszik. Ha ebben az időpontban a következőnek használandó műhold már a horizont felett van, akkor az átváltás végrehajtható, annak időszükségletét a követő antennarendszer újra pozícionálásának sebessége határozza meg. Elektronikus vezérlésű, aktív fázisvezérelt antenna esetében ez gyakorlatilag kiesés nélkül megvalósul. Amennyiben a felkelőben lévő

1. táblázat. John E. Draim: a müholdak folyamatos lefedettségi konstellációi (Forrás: Draim_hemi.ods)

\begin{tabular}{|c|c|c|c|c|c|c|}
\hline $\begin{array}{c}\text { Múhold } \\
\text { sorszáma }\end{array}$ & $\begin{array}{c}\text { Fél } \\
\text { nagytengelyhossz }\end{array}$ & Inklináció & Excentricitás & RAAN & $\begin{array}{c}\text { Perigeum } \\
\text { argumentuma }\end{array}$ & $\begin{array}{c}\text { Közép- } \\
\text { anomália }\end{array}$ \\
\hline 1. & $42164,24 \mathrm{~km}$ & $30^{\circ}$ & 0,28 & $0^{\circ}$ & $-90^{\circ}$ & $0^{\circ}$ \\
\hline 2. & $42164,24 \mathrm{~km}$ & $30^{\circ}$ & 0,28 & $240^{\circ}$ & $-90^{\circ}$ & $240^{\circ}$ \\
\hline 3. & $42164,24 \mathrm{~km}$ & $30^{\circ}$ & 0,28 & $120^{\circ}$ & $-90^{\circ}$ & $120^{\circ}$ \\
\hline
\end{tabular}


műholdat terepakadály takarja, akkor hiába áll megfelelő irányba az antenna, nem jön létre az összeköttetés. Hasonló a helyzet, ha az éppen használt mühold nem a terepakadály nélkül vizsgált horizont alá nyugszik, hanem egy terepakadály mögé. Ekkor még a váltó műhold nem kelt fel, vagyis nincs hová átállni.

Ha több műhold van a horizont felett, akkor az újra pozícionálás magasabb kilövési szögnél is megkezdődhet, vagyis csökken annak valószínúsége, hogy a használt műhold terepakadály mögé nyugszik le. Hasonlóképpen, a felkelőben lévő múhold magasabbra képes emelkedni, ki a terepakadály mögül, és végrehajtható rá az átállás. Az antenna nyalábvezérlő rendszere a műholdak égimechanikai paramétereinek és az állomás üzemelési helyének ismeretében folyamatosan számítja a láthatóságot, és fázisvezérelt anntennarendszer esetén akár arra is képes, hogy a két sugárnyalábot képezve, az egyikkel az üzemelő műholdat követve kommunikáljon, míg a másikkal (természetesen kisebb kapacitást allokálva) mérje, hogy felbukkant-e már a váltó műhold. Így az átváltás mindig alkalmas időpillanatban hajtható végre.

A 4 műholdas módosított Draim-féle északi féltekés lefedésű műholdkonstelláció ötletét összevonhatjuk a szuperszinkron térrész hasznosításával. Draim a szabadalmi leírásban igen megengedően határozta meg a használható pályamagasságokat, vagyis nincs elméleti akadálya a szuperszinkron pályának. Ő maga még 96 órás keringési időre is tervezett. A geoszinkron, illetve a geostacionárius pályáktól eltérően, a szuperszinkron térrészben számos röppálya lehetséges fizikailag, amelyek szolgáltatásnyújtási szempontból egyenértékűek. Ezek közül első közelítésben a perturbációs hatások szempontjából hosszú időre a legkedvezőbbet célszerű választani a röppályatartás hajtóanyagigényének minimalizálása miatt, de egyidejűleg figyelembe kell venni a pályára állítás során végrehajtandó manőverek - elsősorban az inklinációváltási manőverek energiaigényét is. A kezdeti és az üzem során folyamatosan szükséges manőverek össz-energiaigényét végül minimalizálni kell. Emiatt az alábbi pályacsokor elméleti, amely megfelel annak a követelménynek, hogy biztosítsa a folyamatos északi féltekés fedést a lehető legnagyobb kilövési szöghatár mellett, de egyáltalán nem ez az egyetlen lehetséges - még csak nem is az optimális - pálya. Az, csak az indítási hely által meghatározott kezdeti röppálya-inklináció ismeretében számítható ki.

A kilövési szög korlátjának emelése-süllyesztése az átfedés mértékének meghatározásán keresztül leglátványosabban a teljes folyamatos fedés déli határvonalának elmozdulásán keresztül válik érzékelhetővé. Minél magasabbra emeljük a korlátot, annál északabbra valósul meg a teljes fedés. Az alábbi táblázatban leírt paraméterezésű konstelláció esetében nulla kilövési szög esetén (terepakadályok nélküli elméleti horizont) a teljes folyamatos fedés megvalósul az Ausztrália és Madagaszkár legészakibb partvidékei által meghatározott szélességtől (hozzávetőlegesen a déli

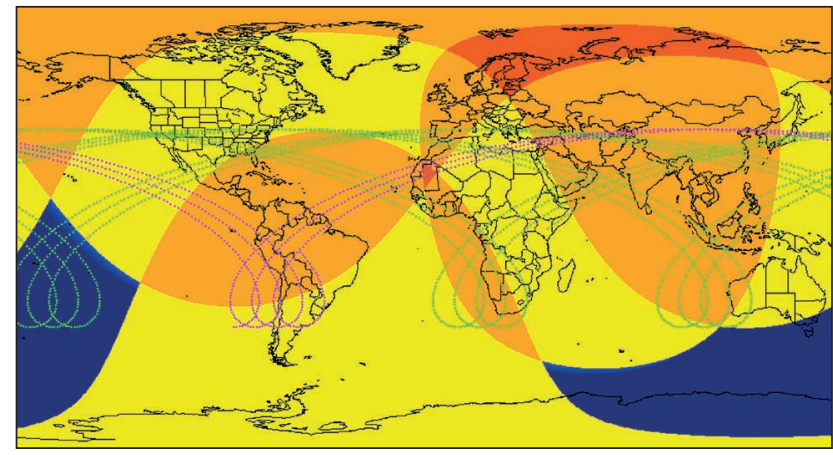

1. ábra. Módosított, 4 múholdas Draim-féle északi hemiszférikus konstelláció lefedettségi térképe egy időpillanatban

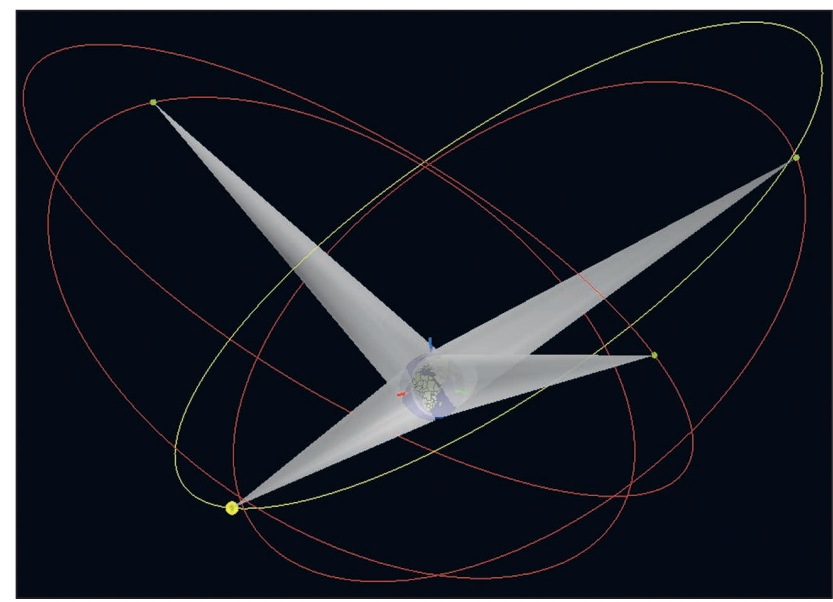

2. ábra. A konstelláció műholdjai, röppályái és a földgolyóra vetített lefedési kúpok

szélesség 12. fokától) északra. Amennyiben a kilövési szögkorlátot $14^{\circ}$-ra emeljük, akkor még mindig nem jelenik meg lefedetlen rész a fő szolgáltatási területben (nincs „Iyuk" a teljes folyamatos fedéssel ellátni tervezett területen), de ennek a területnek a déli határa most már Srí Lanka északi partvidéke, vagyis az északi szélesség 10. foka. A röppálya inklinációjának emelésével a teljes folyamatos fedés déli határa még inkább északra csúszik, azonban ezen a területen belül a kilövési szögkorlát is emelhető. $56^{\circ}$-os inklináció esetén $20^{\circ}$-os kilövési szögkorlát mellett is biztosított a teljes folyamatos fedés, de csak Pakisztán déli partvidékétől (északi szélesség 25. foka) északra.

A példaként alkalmazott konstelláció égimechanikai paramétereit a 2. táblázat tartalmazza. A táblázatban, a Draimféle szabadalommal azonos formátumú leírás érdekében, a közép-anomália szerepel.

A fenti paraméterekkel kialakított műholdpályák földközelpontja 36767 km magasan, a földtávolpontja pedig

\section{2. táblázat. A példaként alkalmazott konstelláció égimechanikai paraméterei}

\begin{tabular}{|c|c|c|c|c|c|c|}
\hline $\begin{array}{c}\text { Múhold } \\
\text { sorszáma }\end{array}$ & $\begin{array}{c}\text { Fél } \\
\text { nagytengelyhossz }\end{array}$ & Inklináció & Excentricitás & RAAN & $\begin{array}{c}\text { Perigeum } \\
\text { argumentuma }\end{array}$ & $\begin{array}{c}\text { Közép- } \\
\text { anomália }\end{array}$ \\
\hline 1. & $66378,14 \mathrm{~km}$ & $40^{\circ}$ & 0,35 & $0^{\circ}$ & $-90^{\circ}$ & $0^{\circ}$ \\
\hline 2. & $66378,14 \mathrm{~km}$ & $40^{\circ}$ & 0,35 & $90^{\circ}$ & $-90^{\circ}$ & $-90^{\circ}$ \\
\hline 3. & $66378,14 \mathrm{~km}$ & $40^{\circ}$ & 0,35 & $180^{\circ}$ & $-90^{\circ}$ & $-180^{\circ}$ \\
\hline 4. & $66378,14 \mathrm{~km}$ & $40^{\circ}$ & 0,35 & $270^{\circ}$ & $-90^{\circ}$ & $-270^{\circ}$ \\
\hline
\end{tabular}


83232 km magasan található, vagyis meglehetősen szuperszinkron magasságban (még a földközelpontot is a szinkronmagasság felett állítottam be, pontosan azért, hogy még csak ne is érintse azt a térrészt a röppálya). Ez abból is látható, hogy a keringési idő 2836,6 perc, vagyis 47 óra és 27 perc, majdnem két teljes nap.

A bemutatott konstelláció alapvetően az északi félteke kiszolgálását biztosítja. A műholdak természetesen áthaladnak a déli félteke fölött is, és amennyiben egy ott tartózkodó földi állomás látókörébe kerülnek, akár még nyújthatnak is szolgáltatást. Azonban ez a fedés nem folyamatos. Amennyiben a teljes Földre kiterjedő folyamatos lefedésre van szükség, más pálya-elrendezést kell választani.

Draim második vizsgált szabadalma, a U.S.Patent 4,854,527 egy ilyen rendszert ír le. Ez a konstelláció mindössze 4, elliptikus szuperszinkron pályán keringő müholddal képes folyamatos globális fedést biztosítani, de csak akkor, ha a terepakadályok hatásától eltekintünk. Mivel a gyakorlatban ez nem megfelelő, ismét szükségessé vált a módosítás. A vonatkozó dinamikus szimulációk bemutatása a https://horvath.space/modified-draim-tetrahedral/ weboldalon láthatók.

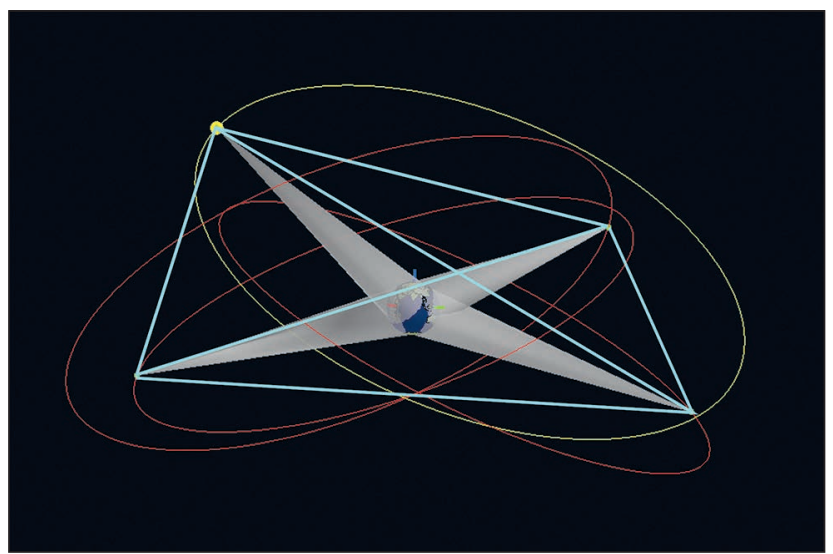

3. ábra. Draim tetrahedrális konstelláció eredeti konfigurációja

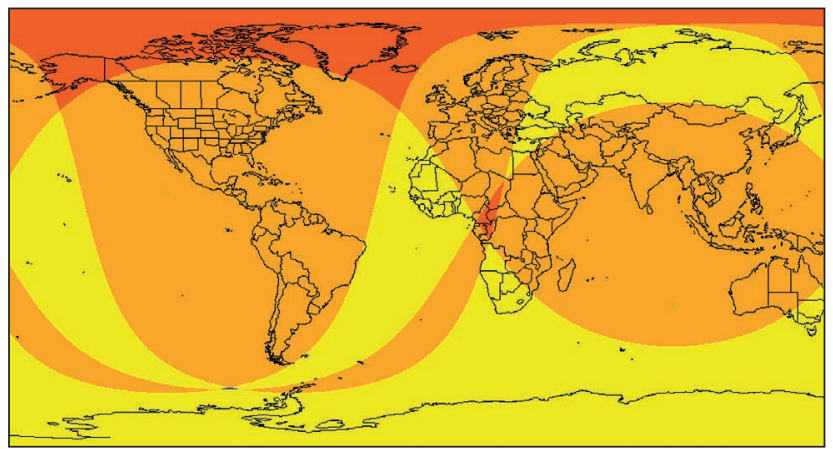

4. ábra. Az eredeti konstelláció lefedettségi térképe
Draim az eredeti, 4 műholdas rendszert tetraéderes (tetrahedrális) konstellációnak nevezte el, mert a 4 mühold egy tetraéder 4 csúcsát alkotja. A szabályos tetraéder lapszöge hozzávetőlegesen 70,53 fok. A szimulációk futtatása során jól látszott, hogy az egyszerű tetraéder megkettőzése és a második tetraéder lapszögnyivel való elforgatása (vagyis gyakorlatilag egy csillagtetraéder létrehozása) biztosította a legnagyobb elérhető kilövési szöget, amennyiben a többi égimechanikai paraméter változatlan maradt.

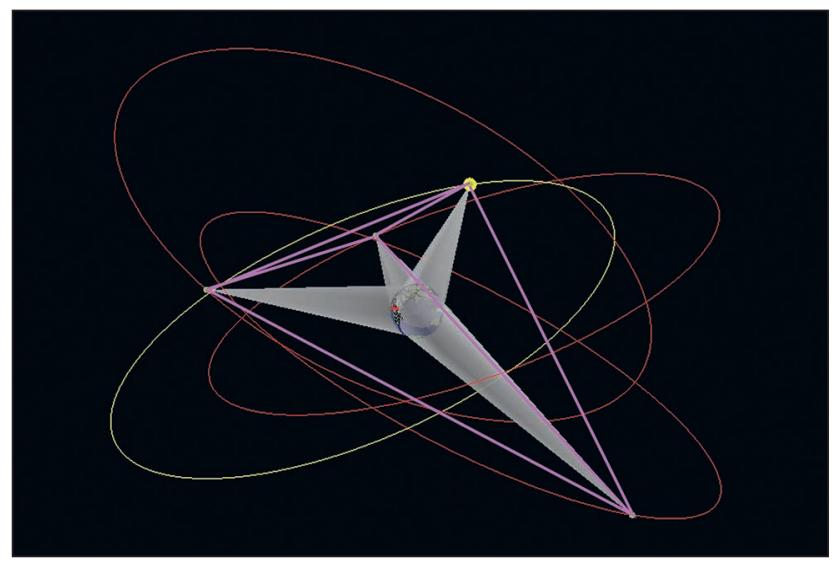

5. ábra. Az elforgatott konstelláció konfigurációja

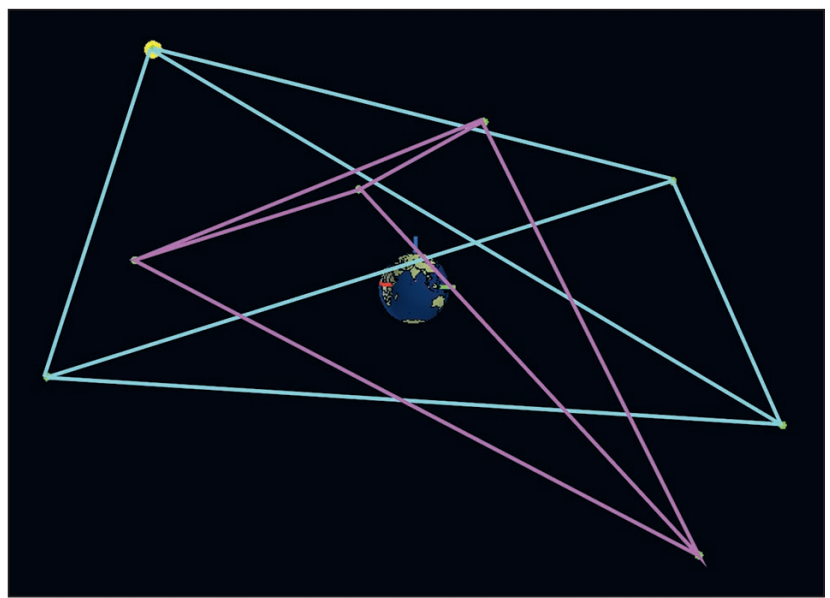

6. ábra. A két tetraéder egyben ábrázolva, a pályák és a sugárkúpok nélkül

Így a globális fedéshez 4 pályasíkon összesen 8 db műhold alkalmazása szükséges, de ennek előnye az, hogy igen nagymértékü átfedések alakulnak ki, vagyis a rendszer jól tartalékolt.

Draim az eredeti szabadalomban igen széles égimechanikai paramétertartományt határoz meg, ami megfelelően testre szabhatóvá teszi a rendszert, a tényleges indítási,

3. táblázat. A SaVi beépített Draim-szimulációjának értékei

\begin{tabular}{|c|c|c|c|c|c|c|}
\hline $\begin{array}{c}\text { Múhold } \\
\text { sorszáma }\end{array}$ & $\begin{array}{c}\text { Fél } \\
\text { nagytengelyhossz }\end{array}$ & Inklináció & Excentricitás & RAAN & $\begin{array}{c}\text { Perigeum } \\
\text { argumentuma }\end{array}$ & $\begin{array}{c}\text { Közép- } \\
\text { anomália }\end{array}$ \\
\hline 0. & $66934,89 \mathrm{~km}$ & $31,3^{\circ}$ & 0,263 & $0^{\circ}$ & $90^{\circ}$ & $0^{\circ}$ \\
\hline 1. & $66934,89 \mathrm{~km}$ & $31,3^{\circ}$ & 0,263 & $90^{\circ}$ & $-90^{\circ}$ & $270^{\circ}$ \\
\hline 2. & $66934,89 \mathrm{~km}$ & $31,3^{\circ}$ & 0,263 & $180^{\circ}$ & $90^{\circ}$ & $180^{\circ}$ \\
\hline 3. & $66934,89 \mathrm{~km}$ & $31,3^{\circ}$ & 0,263 & $270^{\circ}$ & $-90^{\circ}$ & $90^{\circ}$ \\
\hline
\end{tabular}




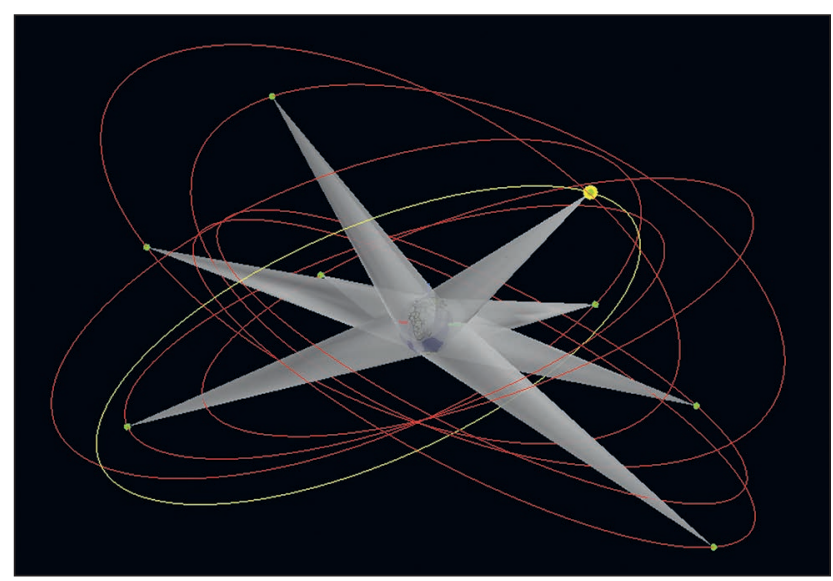

7. ábra. A 8 múholdas, kettős tetrahedrális konstelláció pályái és sugárkúpjai

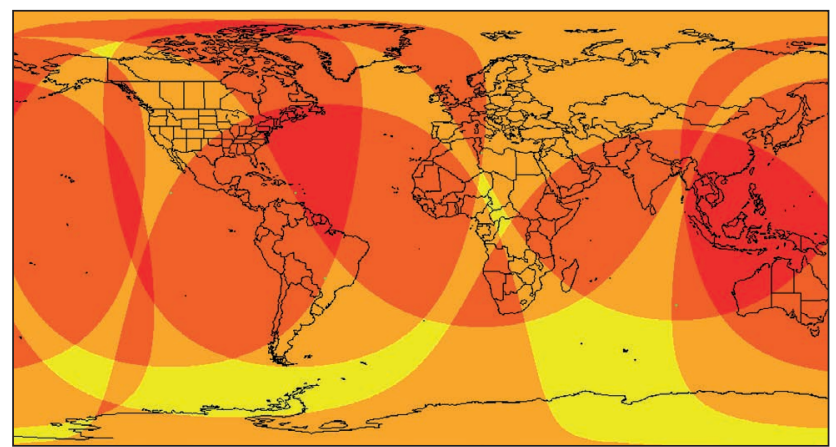

8. ábra. A kettős tetrahedrális konstelláció lefedettségi térképe

pályára állítási lehetőségek függvényében. A kezdeti értékként felhasznált paraméterek a SaVi beépített Draimszimulációjának értékeit a 3. táblázat tartalmazza.

Ezek az értékek a lehetséges legnagyobb kilövési szöget biztosítják, ami mindössze $2,4^{\circ}$. A tetraéder megkettőzésével és lapszöggel történő elforgatásával a kilövési szög $12^{\circ}$-ra emelhető. Ekkor még mindig az eredeti inklinációt használjuk. Mivel az inklináció megváltoztatható paraméter (csak a felszálló csomó helye, a perigeum argumentuma és a közép-anomália / perigeumátmenet ideje kötött), érdemes kísérletezni vele. $45^{\circ}$-ra emelt inklináció mellett a kilövési szöget egészen $20^{\circ}$-ig lehet emelni. Az excentricitás változtatásával kis mértékű hatást lehet gyakorolni a kilö- vési szögre (sokkal kisebbet, mint az inklinációval), ezért ott nem az ideális excentricitást érdemes keresni, hanem inkább a pályára állítást végző rakéta technikai lehetőségein belül kell vizsgálni a megvalósuló átfedésekre gyakorolt hatást. Mivel a jelenlegi katonai VSAT összeköttetés-tervezési gyakorlatunkban a $15^{\circ}$-os kilövési szöget tekintjük alsó korlátnak, láthatjuk, hogy ehhez képest a konstelláció képességei megfelelőek.

Az égimechanikai paramétereket a 4. táblázat tartalmazza.

\section{A HOSSZÚ TÁVÚ ÜZEMELTETÉS KÉRDÉSEI}

A pályára állás érdekében kiszámított sebességváltozáshoz hozzá kell még adni két tételt. Az első a röppálya stabilizálásához szükséges hajtóanyag-mennyiség. A Nap sugárnyomása, a Föld gravitációs mezejének szabálytalansága és a Nap-Hold tömegvonzás hatására a pálya eltorzul, amit kompenzálni kell. Ez azonban nem olyan kritikus veszély, mint akár az alacsony Föld körüli pályán (ahol a magaslégkör fékező hatását kell kiküszöbölni), akár a geostacionárius pályán, ahol a luniszoláris vonzás a meghatározó zavaró tényező, és már minimális eltérés a névleges pályától is csökkenti a szolgáltatásminőséget, illetve akár működésképtelenné is teheti a rendszert. A szuperszinkron konstellációk esetében a névleges pályától való eltérés csak az egyes müholdak szolgáltatási területei közötti átfedés mértékét változtatja meg, ezáltal csökkenhet az elevációs maszk. Amíg az egy elfogadható határ felett marad, addig a szolgáltatás az elvárt minőségben rendelkezésre áll.

Sokkal nagyobb jelentőséggel bír azonban a műholdak hasznos élettartama végén, azok biztonságos kezelése. Jelenleg erre háromféle megoldást alkalmaz az űripar. Az első az alacsony pályán, 4-500 km alatt keringő müholdak esete, ahol a magaslégkör fékező hatása néhány év, legfeljebb évtized alatt megoldja a problémát: a lefékeződő műhold visszalép a légkörbe és ott elég. A következő eset a némiképp magasabb pályán keringő műholdakra vonatkozik, ahol a hasznos élettartam végén a pálya földközelpontját aktív fékező manőverrel a fentebb említett alacsony tartományba süllyesztik, és megint a légköri fékezés hatására veszíti el a műhold az energiáját. Ezek a manőverek hatékonyabbá tehetők fékező vitorlák, ballonok nyitásával, amelyek megnövelik a keresztmetszeti felületet, ezáltal lerontják a ballisztikai együtthatót. Nincs jelenleg megoldás azonban a közepes Föld körüli pályán, és főként a geoszinkron pályamagasságban felhagyott műholdak ke-

4. táblázat. Égimechanikai paraméterek

\begin{tabular}{|c|c|c|c|c|c|c|}
\hline $\begin{array}{c}\text { Múhold } \\
\text { sorszáma }\end{array}$ & $\begin{array}{c}\text { Fél } \\
\text { nagytengelyhossz }\end{array}$ & Inklináció & Excentricitás & RAAN & $\begin{array}{c}\text { Perigeum } \\
\text { argumentuma }\end{array}$ & $\begin{array}{c}\text { Közép- } \\
\text { anomália }\end{array}$ \\
\hline 0. & $66934,89 \mathrm{~km}$ & $45^{\circ}$ & 0,263 & $0^{\circ}$ & $90^{\circ}$ & $0^{\circ}$ \\
\hline 1. & $66934,89 \mathrm{~km}$ & $45^{\circ}$ & 0,263 & $90^{\circ}$ & $-90^{\circ}$ & $270^{\circ}$ \\
\hline 2. & $66934,89 \mathrm{~km}$ & $45^{\circ}$ & 0,263 & $180^{\circ}$ & $90^{\circ}$ & $180^{\circ}$ \\
\hline 3. & $66934,89 \mathrm{~km}$ & $45^{\circ}$ & 0,263 & $270^{\circ}$ & $-90^{\circ}$ & $90^{\circ}$ \\
\hline 0a. & $66934,89 \mathrm{~km}$ & $45^{\circ}$ & 0,263 & $0^{\circ}$ & $90^{\circ}$ & $0^{\circ}$ \\
\hline $1 a$. & $66934,89 \mathrm{~km}$ & $45^{\circ}$ & 0,263 & $90^{\circ}$ & $-90^{\circ}$ & $270^{\circ}$ \\
\hline 2a. & $66934,89 \mathrm{~km}$ & $45^{\circ}$ & 0,263 & $180^{\circ}$ & $90^{\circ}$ & $180^{\circ}$ \\
\hline 3a. & $66934,89 \mathrm{~km}$ & $45^{\circ}$ & 0,263 & $270^{\circ}$ & $-90^{\circ}$ & $90^{\circ}$ \\
\hline
\end{tabular}


zelésére. Itt csak annyi történik, hogy a gazdaságilag hasznosítható térrészből kis mértékben kimozdítják a műholdat egy magasabb pályára, ahonnan a természetes fékező hatások belátható időn belül nem fogják azt újból visszajuttatni az üzemelő műholdak környezetébe. Ez azonban a problémát nem szünteti meg, csak elodázza (és pontosan ez az egyik oka annak, hogy új, a jelen tanulmányban leírthoz hasonló, eddig még nem használt pályákat kell keresni). Éppen ezért felelős tervezőnek - főként olyan műholdak esetében, ahol nem a gazdasági hasznosság a műhold létének legfőbb értékmérője -, gondoskodnia kell a probléma végleges megoldásáról.

Három lehetséges út van erre:

1. a műhold visszahozatala a Föld légkörét metsző pályára;

2.a mühold kigyorsítása a Föld gravitációs teréből egy erősen elliptikus Nap körüli pályára, amelynek eredményeként a Napot megközelítve annak sugárzásának hatására semmisül meg;

3. pályára állás a Hold körül, ahol a Hold gravitációs inhomogenitásának hatására a pályája instabillá válik és becsapódik.

Az alacsony Föld körüli fékezőpályára való visszahozatal energiaigénye összemérhető az onnan való kijuttatás energiaigényével, és a müholdnak kereszteznie kell az összes egyébként használt pályatartományt. Továbbá, amennyiben a légköri fékezés nem sikeres, akkor a mühold egy nehezen előre jelezhető pályára áll, amely idővel természetesen beledegradálódik a légkörbe, de addig is foglalkozni kell a kontrollálhatatlanná vált műholddal. A Napba irányuló pálya energiaigénye pedig hatalmas.

Az előzőekkel ellentétben a Hold elérése nem irreális cél. Számos űrszonda járt be olyan alacsony energiaigényű transzferpályát, amely ugyan sokkal lassabban (hónapok alatt, de készült olyan pályaterv is, ami egy évet igényel), viszont minimális energiabefektetéssel eléri a Holdat, és ott fékező manőver nélkül, pusztán a tömegvonzás hatására kialakul a keringőpálya. A tömegkoncentrációk hatására bekövetkező zuhanás ideje is igen hosszú lehet (a tényleges pályától függően akár évekig eltarthat), de elkerülhetetlen, a Hold körül stabil alacsony röppálya csak nagyon pontos tervezéssel létesíthető, vagyis ezeket a stabil pályákat elkerülni (ami jelen esetben a cél) igen jó eséllyel sikerül.

A Holdra zuhanó műholdak jelenleg és a belátható jövőben nem veszélyeztetik az emberiséget, és ha egyszer ott állandó emberi tevékenység kezdődik, az addig oda juttatott műholdak maradványai még nyersanyagként is szolgálhatnak.

\section{ÖSSZEGZÉS}

A kellően magas minimális kilövési szög a katonai összeköttetés-tervezési gyakorlatban különös fontossággal bír. A kereskedelmi múholdas rendszerekben a minimális kilövési szöget elsősorban a rádiótechnikai hatások korlátozzák ( $5^{\circ}$ alatt a légköri szcintilláció miatt az összeköttetésbe nagy teljesítménytartalékot kell tervezni). A telepítés tervezőjének és végrehajtójának ebből kiindulva olyan telepítési helyet kell találni, ahol a megfelelő zavartalan kilátás biztosított. Ebben meglehetősen nagy szabadságot élveznek ha egy adott helyről, ingatlanról a műhold takarásban van, akkor máshol kell helyet bérelni. A katonai tervező részére ez a szabadság nem adott. A vezetési pont, vagy az ahhoz tartozó műholdas távközlési komplexum (amennyiben ezek fizikailag megbonthatók, de például egy mozgó vezetési csoportot támogató rádiós vezetési pont esetében ez a megbontás nem lehetséges) telepítési helyének meghatározásakor számos más, az erők megóvását és a múveleti szabadságot biztosító szempontot is figyelembe kell venni. Éppen ezért létfontosságú, hogy minél kevesebb beépített korlátozó tényezővel kelljen számolni - annál jobban leszünk képesek hozzájárulni az összhaderőnemi művelet sikeréhez.

Draim eredeti konstellációi nem feleltek meg ennek a követelménynek, azonban a tervezési elvek pontosan illeszkednek a műveletvezetésben alkalmazásra tervezett müholdas távközlési rendszerekkel szemben támasztott követelményekhez: folyamatos fedést biztosítanak a műveleti területen, miközben a müholdak relatív elmozdulása elfogadható.

A szimulációk igazolták, hogy az égimechanikai paraméterek eredetileg meghatározott tartományokban tartásával, a konstellációk alakzatának módosításával (a műholdak számának növelésével) a minimális kilövési szög radikálisan emelhető. $A z$ is láthatóvá vált, hogy a megnövelt műholdszám növeli a rendszer tartalékoltságát.

A katonai alkalmazás során még egy szempontot szem előtt kell tartani: a világűr műveleti terület. Számos lehetősége van egy ellenérdekelt félnek az űrrendszerek szolgáltatásminőségének csökkentésére, végső esetben azok kiiktatására. Ezek egy része (például a földi szegmens elleni támadások vagy a kibertámadások) független a röppályától.

A kinetikus támadások vagy a rádiózavarás esetében azonban vagy magát a támadás végrehajtását tudja megnehezíteni a megfelelően megválasztott röppálya (például a nagy pályamagasság miatt a támadás időablakának megnyújtásával), vagy pedig a támadás tényének felfedését könnyíti meg. Amennyiben egy relatív elmozdulással járó pályán keringő müholdon a rádiózavarás hosszabb időn keresztül jelentkezik, az igen valószínűvé teszi, hogy irányított antennával, a müholdat követve történik a zavaró jel kisugárzása. Hasonlóképpen, a geostacionárius pályán egy megközelítéskor, kötelékrepüléskor lehet arra hivatkozni, hogy a természet erőinek játéka sodorta oda a megközelítő mủholdat, de a szuperszinkron pályán ugyanez az érvelés hamis. Oda csak célzott manőverrel lehet eljutni. Ezek a jellemzők hatékony passzív védelmet képesek biztosítani az ürszegmensnek.

A bemutatott konstellációk hátránya, hogy míg akár egyetlenegy geoszinkron vagy geostacionárius mủholddal is lehetséges piacra lépni és a kormányzati alkalmazások, katonai műveletvezetés részére megfelelő szolgáltatásokat nyújtani, addig ezek a rendszerek 4-8 mühold legyártását és pályára állítását igénylik. További hátrány, hogy a rádiótechnikai és az adatátviteli funkciók még a geoszinkron pályamagasságnál is több kihívást jelentenek a tervezőknek.

Mindezzel szemben áll azonban a védettség a természetes (a sugárzási öveken való áthaladás) és a mesterséges (törmelékképző ütközések) eredetű káros hatások ellen, és a várhatóan hosszú évtizedekig zavartalanul rendelkezésre álló pályatartomány, amelyben sokkal nagyobb szabadsággal tervezhetők a röppályák, mint a geostacionárius pályán. Továbbá, az alacsony Föld körüli pályához képest sokkal alacsonyabb üreszközszámmal elérhető a globális vagy a hemiszférikus fedés.

Napjainkban a világür gazdasági, politikai, katonai jelentősége korábban soha nem látott mértékben növekszik. Az a mód, ahogyan évtizedeken át hasznosítottuk, nem fenntartható. A további növekedés egyik útja, hasonlóan a nagy földrajzi felfedezések időszakához, az új területek megismerése és meghódítása. Ez a tanulmány erre mutatott egy lehetséges utat. 


\section{KÖSZÖNETNYILVÁNITTÁS:}

A publikáció elkészítését az Innovációs és Technológiai Minisztérium Új Nemzeti Kiválóság Program támogatta, a Nemzeti Kutatási, Fejlesztési és Innovációs Hivatal szakmai együttműködésével. ÚNKP azonosító: ÚNKP-19-3-INKE-22. http://unkp.gov.hu

A dinamikus szimulációk a SaVi - Geomview szoftverekkel készültek. https://savi.sourceforge.io

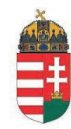

NEMZETI KUTATÁSI,

FEJLESZTÉSI ÉS INNOVÁciós HIVATAL

FELHASZNÁLT IRODALOM

Phillips, Trina Marie; Cole, August. Visions of Warfare. 2036, Norfolk: Allied Command Transformation, 2016. elérés: 2020. 09. 14. https://www.act.nato.int/images/ stories/events/2012/fc_ipr/visions-of-warfare-2036.pdf;
Durrani, Haris A. „The Bogotá Declaration: A Case Study on Sovereignty, Empire, and the Commons in Outer Space". Columbia Journal of Transnational Law, 2017. december 5. Elérés: 2020. 09. 05. http://blogs2.law. columbia.edu/jt/the-bogota-declaration-a-case-study-onsovereignty-empire-and-the-commons-in-outer-space/;

Declaration of the first meeting of equatorial countries (Adopted on December 3, 1976), Elérés: 2020. 09. 14, https://www.jaxa.jp/library/space_law/chapter_2/2-2-12_e.html;

Riebeek, Holli. Catalog of Earth Satellite Orbits. Elérés: 2020.05.17. https://earthobservatory.nasa.gov/features/ OrbitsCatalog;

Matignon, Louis de Gouyon. „The Kessler Syndrome”. Space Legal Issues, 2019. március 27. https://www. spacelegalissues.com/space-law-the-kessler-syndrome/; Draim, John E. Satellite continuous coverage constellations, United States Patent nr. 4,809,935, 1989 március 7. https://patentimages.storage.googleapis. com/47/7a/20/5fdfadfb873511/US4809935.pdf;

Draim, John E. Tetrahedral multi-satellite continuouscoverage constellation, United States Patent nr. 4,854,527, 1989 augusztus 8. https://patentimages. storage.googleapis.com/49/1a/3b/603f9197c53b6c/ US4854527.pdf.

\section{Robert Moore}

\section{Kurszk - Az atom-tengeralattjáró tragédiájának története}

Robert Moore újságíró alapos kutatómunka nyomán tárja az olvasók elé az orosz Kurszk atom-tengeralattjáró katasztrófájának történetét. 2000. augusztus 12-én, 11 óra 30 perckor két hatalmas robbanás rázta meg a Barents-tenger vizét. A világ legnagyobb harci tengeralattjárójaként ismert Kurszk süllyedni kezdett a tengerfenék felé. A szakértői vizsgálatok megállapították, hogy kémiai eredetű robbanás történt, ugyanis a magas koncentrátumú hidrogén-peroxid beszivárgott a torpedóvetőcsőbe, ami a sárga- és vörösrézzel reakcióba lépve láncreakciót váltott ki. A tengeralattjáró első két rekeszében tartózkodó 45 tengerész valószínűleg azonnal meghalt. Két perc tizenöt másodperccel később újabb robbanás rázta meg a hajót, ami arra utal, hogy a tengeralattjáró a fenéknek ütközött, és ott újabb torpedók robbantak fel. A második robbanást követően a személyzet lekapcsolta az atomreaktorokat, hogy megelőzzék a nukleáris katasztrófát. A robbanás feltépte a 3. és 4 . hajórekesz zárófalát, és a beáramló víz miatt az ott tartózkodók mindannyian meghaltak. A robbanást a 6., 7., 8. és 9. rekeszekben dolgozó 23 tengerész élte túl. A vész-energiaellátás lassan kimerült, a legénység körül teljes lett a sötétség és csökkenni kezdett a hőmérséklet.

A túlélők mentésére küldött orosz mentőkompok akkumulátorai túl gyorsan lemerültek, és feltöltésük rendkívül körülményes volt. Sikertelennek bizonyult az első dokkolási kísérlet is.

2000. augusztus 16-án az orosz kormány elfogadta a brit és a norvég kormány segítségét. A norvég mentőegység augusztus 19-én ért a helyszínre, a brit mélytengeri búvárok pedig másnap megállapították, hogy a 9. rekeszt - ahol a Kurszk katasztrófájának túlélői a robbanás után összegyűltek - víz árasztotta el, túlélőket találni reménytelen. 2001 őszén a tengeralattjáró törzsének legnagyobb részét felszínre hozták, és a roncsot az Orosz Flotta roszljakovói hajójavító mühelyébe vontatták. A 118 fős szerencsétlenül járt legénység 115 tagjának holttestét megtalálták és azonosították.

Robert Moore oknyomozó munkája során személyesen is felkereste azt a bázist, ahol a Kurszkot őrzik. Az amerikai újságíró magas rangú orosz katonákkal készített interjúkat, találkozott az áldozatok családtagjaival, valamint a mentő alakulatok személyzetével.

A GABO Kiadó által 2018-ban megjelentetett cérnafúzött, keménytáblás könyv terjedelme 368 oldal. 3990 Ft-os áron kaptaható a könyvesboltokban, illetve 15\%-os kedvezménnyel közvetlenül a GABO Kiadótól (www.gabo.hu) is megrendelhető. (W.T.) 